\title{
The political economy of regulating retail electricity price caps in a rising cost environment
}

\author{
Paul Simshauser and Kay Laochumnanvanit ${ }^{1}$ \\ AGL Energy Ltd \\ Level 6, 144 Edward Street \\ Brisbane, Qld, 4000. \\ August 2012
}

\begin{abstract}
Australia's highly competitive energy market experienced sustained network-driven tariff increases at multiples of the general inflation rate from 2008-2012. This eventually became a toxic issue for policymakers and in one region resulted in regulated tariff caps in the competitive market being set below long run costs. Doing so runs a high risk of damaging competition, the flow of investment, and following an inevitable price correction, a subsequent media assault capable of inducing a repeat cycle.
\end{abstract}

Keywords: Electricity Prices, Price Regulation, Energy Policy. JEL Codes: D24, L11 and Q48.

\section{Introduction}

By most measures, Australia's National Electricity Market (NEM) has been a successful microeconomic reform. Designed throughout the early-1990s and implemented by 1998, it led to substantial gains in productive, allocative and dynamic efficiency - noting that most these gains came from the wholesale market. ${ }^{2}$ The NEM has been credited with contributing an additional \$2 billion per annum to Australia's Gross Domestic Product (Parer, 2002; NCC, 2003).

Unsurprisingly, Australia's 45,000MW NEM has long been acknowledged as one of the more successful microeconomic reforms of a power industry globally (IEA, 2005).

But while the NEM's wholesale market performance has been a beacon for governments in the region examining energy market reform, there is considerable unfinished business at the retail level. ${ }^{3}$ Despite the intensely competitive nature of the wholesale and retail markets, price controls or 'regulated price caps' remain a policy constraint in three of the NEM's four primary regions (i.e. Queensland, New South Wales and South Australia). Only Victoria has liberalized its retail market. Regulated retail price caps do not fit neatly with a deregulated, energy-only wholesale market as California demonstrated in 2000. The better view is to establish a competitive framework and allow the market to determine the price, quantity and quality of electricity services.

In many respects, regulated retail price caps in the NEM were barely worth a mention from 1998 to 2007. During this first 10 year period, the market was oversupplied and thus it delivered reliable, competitively (i.e. low) priced energy. With few exceptions, regulated price caps allowed competition to flourish at or below the set levels, and thus the NEM had, in the main, been a good news story for consumers. However, the oversupply of generation capacity was gradually exhausted and during 2008 the market virtually imploded via drought-induced wholesale price shocks. With wholesale prices far exceeding the wholesale energy cost allowance contained within regulated tariff caps in 2008, the adverse effects of price regulation in competitive markets had finally been revealed in the NEM, although in a less dramatic manner than the Californian experience. The price shocks were transient and the market eventually stabilized. Nonetheless, the marginal cost of supplying an additional customer during 2008 exceeded prevailing regulated price caps, and in the event the NEM experienced its first energy retailer collapse with a further collapse two years later. ${ }^{4}$ 
But just as the wholesale market began to settle, network price increases began to rise at multiples of the general rate of inflation following substantial new capital investment. These large and sustained upward movements in monopoly transmission and distribution network charges were approved under five-year rate cases, and were thus 'locked-in' by the (Federal) Australian Energy Regulator. But in the NEM, State Governments determine whether any regulatory price cap is to be applied to the competitive retail market at the regional level. In the event, State Governments set economic policy (i.e. the regulatory framework to be used) and a State Regulator then implements that framework. In all cases, a regulated price cap comprises allowances for (1) wholesale energy costs, (2) retail operating costs and margins, and (3) a pass-through of the (federal regulatory-determined) monopoly network charges.

While sharp headline electricity price increases were being driven by rising monopoly network charges, they were being further compounded by the cost impacts of renewable and carbon tax policies as well. As a result, some jurisdictional governments and/or regulators began to reexamine the manner in which the wholesale and retail cost components of regulated tariff caps were set. This became most evident during 2012 and has, in our opinion, been primarily driven by a broader 'cost of living' thematic amongst the Australian population, and amplified by the media. In simple terms, year-on-year electricity price increases became a toxic issue - key to this was the striking rate-of-change in electricity tariffs rather than the absolute tariff itself. As this article later reveals, the media locked-on to the rate-of-change price story, and government involvement in unit price rise announcements further intensified media interest. Given this situation and the political economy of electricity prices, an inherent regulatory bias may have emerged to lean on electricity price caps. Jurisdictional governments and regulators can do little to reduce network charges in the short run because these are set federally under five-year rate cases. The wholesale and retail cost allowances, on the other hand, are determined by local regulators annually. The wholesale market is now once again structurally oversupplied, and so a prima facie opportunity exists to offset rising network costs by reducing the wholesale cost component of the regulated price cap.

This occurred in Queensland. The Government outsourced economic policy (i.e. the regulatory framework) to the regulator, and the regulator in turn designed a framework which had the effect of leaning on the wholesale cost allowance. This was achieved by removing any reference to long run marginal costs from the regulated retail price cap calculation process, and reverting to a somewhat narrow description of what constitutes an efficient hedge portfolio of a competitive retailer - essentially relying on short run spot and contract prices only. ${ }^{5}$ In the event, energy retailers who had written long-dated Power Purchase Agreements or invested in fixed power assets found their businesses being marked-to-market by a regulatory authority, rather than the forces of the competitive market.

To be clear, it is not the role of a regulated tariff cap to somehow manufacture or facilitate normal investment returns on fixed power assets or on Power Purchase Agreements at all points throughout an energy market business cycle. In an oversupplied energy market, firms that have made long term commitments should prepare themselves for losses at the margins and at varying levels of intensity given overcapacity. But conversely, those same firms would presume, quite reasonably, that the intensity of losses would be delivered to them by market forces, not manufactured or intensified by a regulator using highly imperfect information and through the use of regulatory instruments. As Simshauser (2012) explains, it is most unlikely that the approach of using short run dynamics to regulate a clearing price would be applied to an inefficient monopoly. ${ }^{6}$ And noting that regulated price caps serve no economic function in workably competitive markets in the first place, if the use of short run dynamics would not be used to regulate a monopoly, it is also unlikely that it might be applied to an intensely competitive energy pool without consequence, bearing in mind that Queensland was only recently ranked the fifth most competitive retail energy market in the world (VasaETT, 2012). The Queensland 
regulator's decision to set the artificial price cap considerably below the long run marginal cost of supply was met with a degree of shock by the energy industry. To compound matters, two months after the determination, the wholesale market experienced an upward step-change in wholesale prices. Some competitive retailers were left facing the reality that not only was the price cap sub-economic given past commitments, but sub-economic for marginal business as well from a wholesale energy cost perspective. ${ }^{7}$

The NEM jurisdictions of New South Wales and South Australia, which also maintain price cap regulations in their intensely competitive markets, are now examining their wholesale energy cost allowances following the Queensland decision. Contagion, for lack of a better description, seems more than a theoretical possibility at the time of writing. ${ }^{8}$ From a political perspective, following Queensland's approach enables sharply rising network charges to be partially offset, albeit by forcing lower or negative margins upon the competitive industry segments by way of regulatory instrument. Predictably however, regulated retail price caps now appear at the top of stock analyst and corporate risk registers within the NEM. ${ }^{9}$

The purpose of this article is to outline observable lessons arising from setting suboptimal price caps in competitive energy markets. For clarity, this analysis commences with the presumption that workable competition exists at the wholesale and retail level, and that monopoly poles and wires businesses continue to face price regulation with their charges passed through in full. In Section 2 we provide an overview and outlook for retail electricity prices in the NEM. Section 3 reviews the purpose of price regulation and identifies a possible chain-reaction of events that may follow a price-suppression scenario. In Section 4 we present two important case studies while Section 5 examines switching velocity and investment under conditions of price suppression. Section 6 then analyses the reaction of the media to price increases announced by private companies in a deregulated region, and contrasts this with price increases where governments are involved in the price determination process. Our concluding remarks follow.

\section{The history and outlook for residential electricity prices in the NEM}

Despite an elongated period of electricity tariff stability, or perhaps because of it, the recent prognosis for electricity prices in the NEM has been one of sustained upward pressure. Figure 1 presents a 59-year history of residential electricity prices in the NEM region of New South Wales and its capital city, Sydney, in nominal dollars and real 2012 dollars. Two distinct periods of sustained tariff increases are evident; from the late-1970s through to 1985, and again from 2007. Both periods align with substantial increases in the power system's capital stock as Simshauser and Catt (2012) explain. More recently, the capital flows have been dominated by investments into the network 'poles and wires'. Note that in real terms, electricity tariffs were falling or constant from 1986 through to 2007. Thereafter, tariff increases have been marked in line with sharp growth in network capital investment. ${ }^{10}$ 
Figure 1: $\quad 59$ year history of residential electricity prices in New South Wales

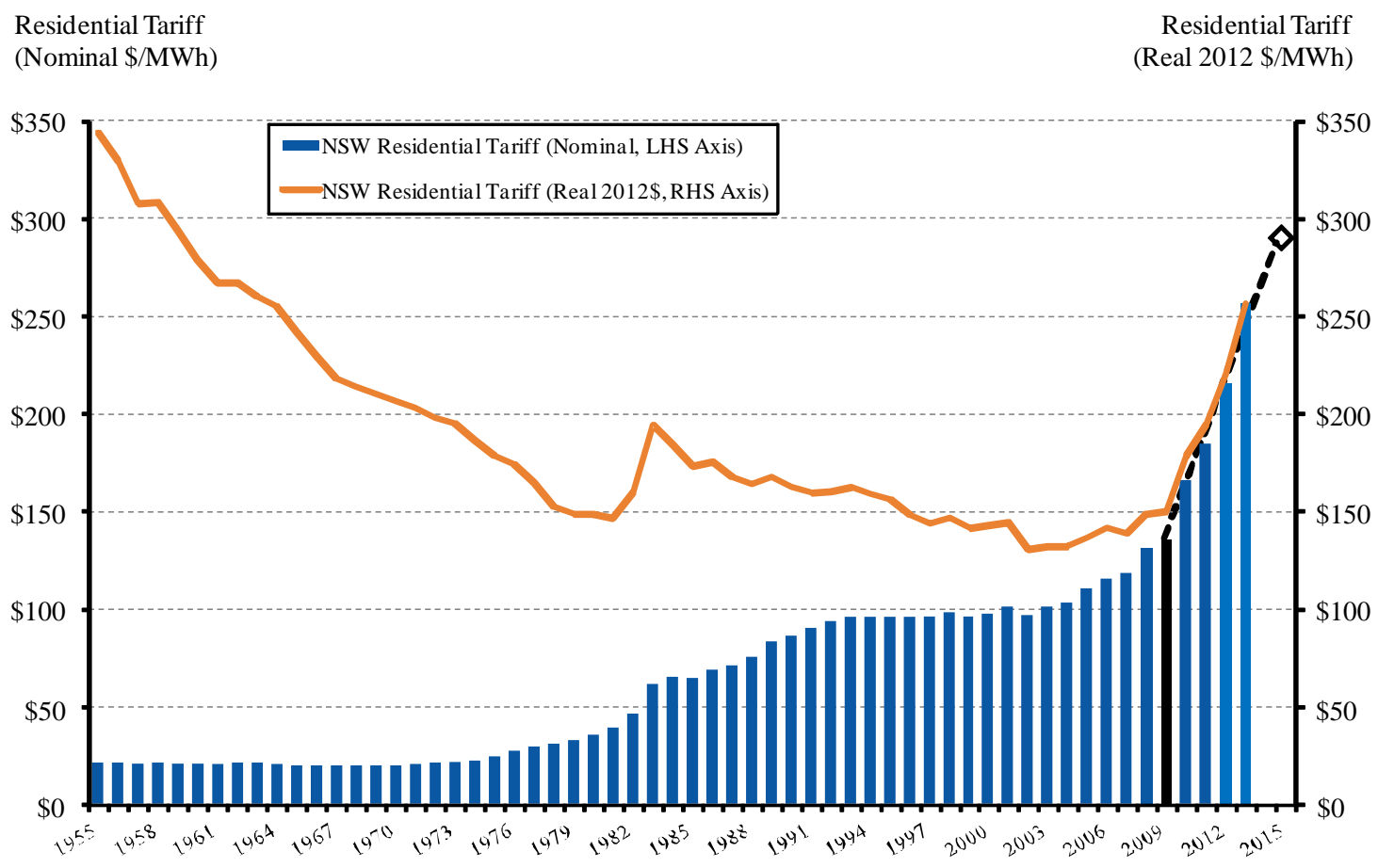

Source: Simshauser (2012).

A dominant cause of the recent run-up in electricity tariffs can be traced to rapidly rising household peak demand and a simultaneous tightening of reliability standards at the distribution network level, with the latter now a clear candidate for reform to reduce the incidence of 'gold plating'. On demand, average household consumption in New South Wales in 1955 was about $2 \mathrm{MWh}$ per annum. By the 1970s this had doubled to $4 \mathrm{MWh}$, and had virtually doubled again by 2008 to 7.5MWh (Simshauser, Nelson and Doan, 2011). But more importantly, growth in peak period demand has been more pronounced.

To illustrate the nature of the peak load problem, we have analysed 3000 randomly selected residential customers in Sydney, New South Wales who have a 'smart meter'. The granularity of this data allows us to examine the shape (or peakiness) of household power demand rather than just the aggregate quantity consumed. In Figure 2, over 52.5 million meter readings from the 3000 residential customers during FY2010 have been condensed into two household load curves; the first being average daily consumption throughout the year, and the second being average consumption of those households on a critical event day, i.e. the hottest day of the year on 22 November 2009 where temperatures reached $40^{\circ} \mathrm{C}$. The households in Figure 2 consume an average of about $6.7 \mathrm{MWh}$ per annum (below the regional average of about 7.5MWh).

Nonetheless, it is the shape of the load curve that is of relevance to our analysis. On the critical event day, total energy consumption is up by $78 \%$ while peak demand is up by $90 \%$, compared to average. 
Figure 2: $\quad$ NSW household demand - annual average vs. critical event day

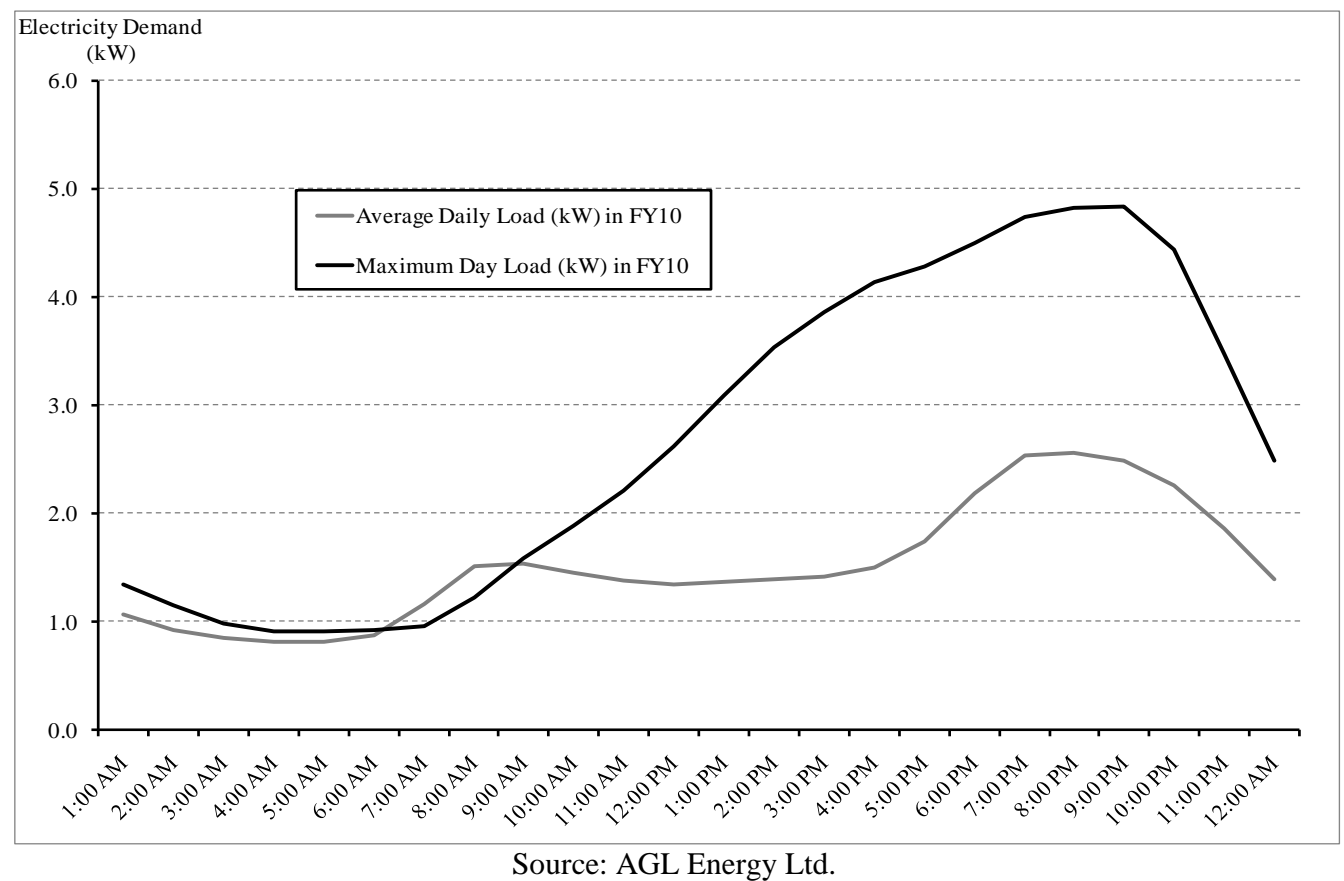

Electricity is not yet able to be stored economically and therefore there is no inventory for which to draw upon during periods of intense demand. And unlike time-delays with transport congestion, electricity congestion can only be solved through blackouts, which is politically unacceptable. As a result, power system infrastructure and generating capacity is generally augmented to meet projected instantaneous peak demand (plus a margin for forecast errors and plant outages). The capital cost of doing so is non-trivial. In the Queensland region for example, fully $\$ 900$ million of capital has been deployed within the $\$ 8$ billion metropolitan distribution network serving the greater Brisbane area ${ }^{11}$ but is used by electricity consumers for, on average, just 3.5 (non-contiguous) days per annum. ${ }^{12}$ Despite this appalling asset utilization rate, the cost of such investments must be recovered from consumers throughout the year. Any requisite peak load generating capacity would only add to this cost.

If peak demand growth continues at pace, ongoing tariff increases seem predictable. Indeed, in a recent article published in The Electricity Journal by Simshauser, Nelson and Doan (2011), electricity tariffs for residential consumers in Queensland and New South Wales for the historic year of 2008 were examined and then projected forward to 2015 and found that prices would double (this has been incorporated in Figure 1 as the 'dashed' line series). The more detailed breakdown of the component increases or the 'waterfall chart' from that article have been reproduced in Figure 3. Note from Figure 3 that the average tariff was about \$136/MWh in 2008, and is predicted to rise by more than $100 \%$ by 2015 . While rapidly rising peak demand was noted as the primary driver of the increases, cost increases were also expected to be compounded by a combination of greenhouse gas-related technology switching from low cost coal to higher cost gas, fuel prices linking with global fuel indices, rising capital costs and costs of capital and of course rapidly rising network expenditure. 
Figure 3: $\quad$ Comparative analysis of electricity tariffs in 2008 and 2015

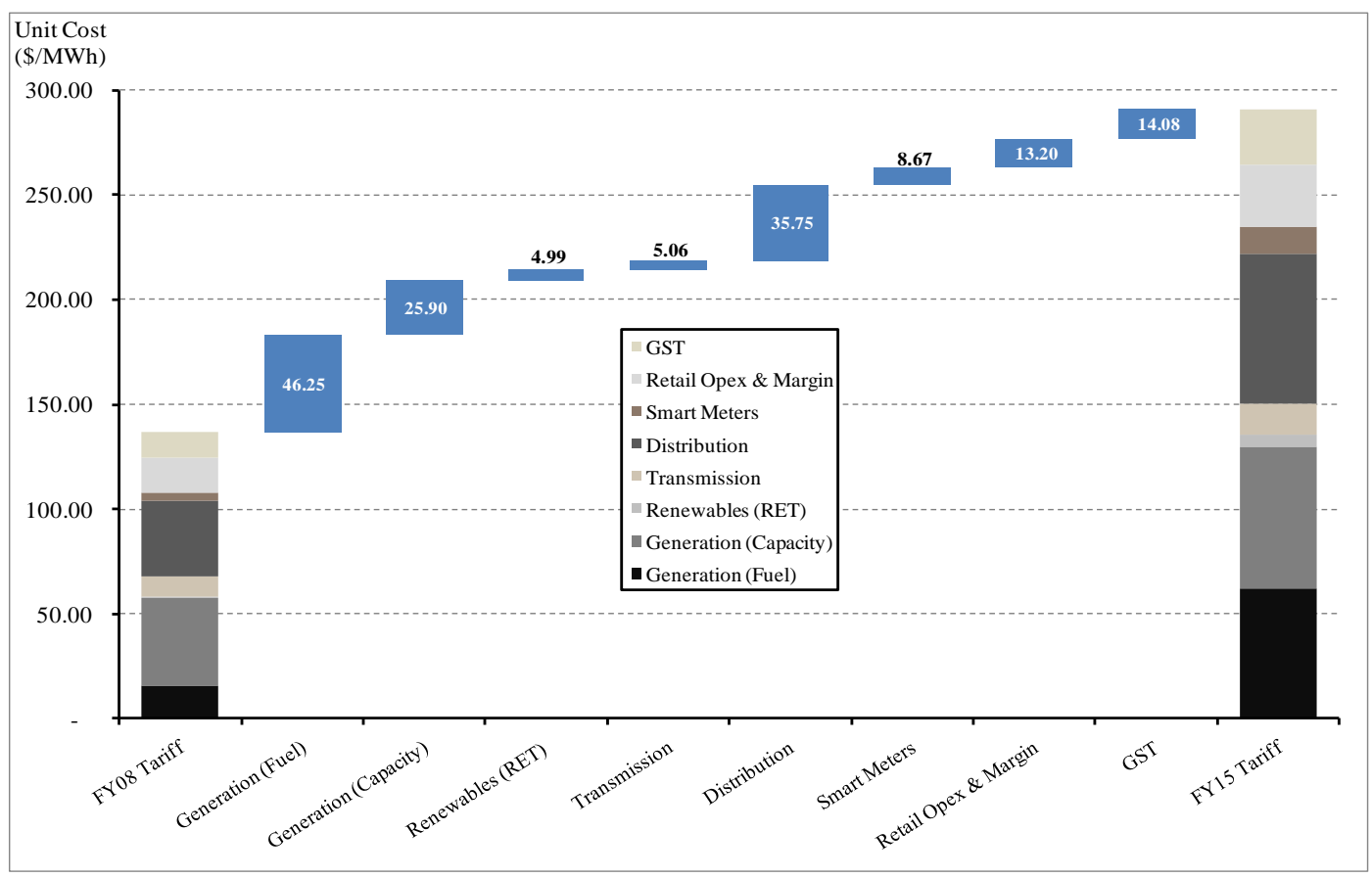

Source: Simshauser, Nelson and Doan (2011)

Ultimately these sharp, year-on-year tariff increases attracted the attention of the mainstream media under the banner of 'cost of living' increases. The response in Queensland, which experienced similar increases to New South Wales as Simshauser, Nelson and Doan (2011) noted, was to regulate the retail price cap below industry long run sustainable costs by misspecifying how a prudent energy retailer would hedge their load under conditions of an intensely competitive market environment. ${ }^{13}$ In effect, it represented an episode of regulatory-induced 'price suppression'.

\section{The purpose of price regulation and the effects of regulatory-induced price suppression}

One of the most crucial issues when designing and implementing price regulation is to clearly define the public policy objective function. If public policy does not have a clearly articulated purpose, it runs a high risk of distorting the market to which it is applied. The case for regulating the prices of a monopoly distribution network business, for example, is clear. Profit seeking monopoly network businesses, left to their own devices, will exercise market power and raise prices above efficient levels and extract sustainable economic rents. Consumers will pay more for electricity services than they should, and this would quite rightly be of concern to policymakers. Price regulation under such conditions is entirely appropriate and is generally designed to drive industry efficiencies, and in the event, determine how subsequent efficiency gains are shared between the monopoly producer and the consumers.

Price regulation also has a genuine role to play in a market transitioning from a monopolistic to a competitive environment. During the early phases of a reform, competition is likely to be inadequate, and incumbent(s) may have considerable market power. As a result, consumer protection is warranted. A regulated 'price cap' can in this instance be designed to provide consumers with a 'safety net'. But policymakers need to think carefully about how this is implemented. If a regulated price cap is set too low, competition will be stifled and any envisaged transition to an intensely competitive market will fail to occur right from the outset. As Yarrow (2008) explains in some detail, a price cap in such a market might well be set at a level higher than an equivalent regulated monopoly if competition is to be facilitated. The issue 
here is that applying an 'equivalent regulated monopoly price' as a potentially binding cap in a competitive market heightens perceived future risks of profits being socialized, with losses being privatized. Because prices in competitive markets inevitably cycle above and below total average cost across the business cycle, applying a regulated monopoly price approach to such a competitive market would see episodes of high prices bind at the regulated cap (i.e. industry profits socialized) whereas episodes of low prices would be unavoidable due to competition (i.e. industry losses privatized). The latter is, of course, expected in competitive markets but the former is not, and in practice may have the effect of truncating normal expected returns. Most importantly, Yarrow (2008) highlights that consumers have both short and long run interests, and while regulating prices down (i.e. price suppression) may deliver short term benefits to customers, in the long run, customers will always be better served by a competitive market than a regulator acting with imperfect information. This is an important concept - in the long run, consumers will be better served by intense competition and subsequent innovation, than economic regulation using imperfect information.

A more important concept is that once a market is 'workably competitive', price regulation ceases to have an economic function (Simshauser, 2012). Regulators act with highly imperfect information, and the information set required to form a clearing price in a workably competitive market increases exponentially as the number of players in a market increases. It is difficult to set an efficient static annual price under conditions of a monopoly. It is therefore simply an impossible task for a central agency to correctly define the truly "efficient" stream of future prices in a workably competitive market given the vast amount of information which is impounded in dynamic final clearing prices.

If price regulation remains a policy constraint in workably competitive markets, and has an objective of reducing customer hardship given the essential service nature of electricity, it will fail. A price that is low enough to reduce energy customer hardship will almost certainly damage competition, innovation and the flow of investment, none of which is in the best long term interests of consumers. In competitive markets, energy customer hardship must be dealt with through alternate policy instruments such as concessions and rebates or other forms of assistance, and ideally, through progressive funding sources utilizing the taxation and transfer systems for delivery. These are all important principles, but most important is the fact that price regulation serves no economic function in a workably competitive market.

One likely asymmetry of setting regulated price caps in workably competitive energy markets is that the consequence of regulatory error from high-pricing should, in theory at least, be lower than the consequences of price suppression. The reason for this is that a range of competitors, products and options would be available to consumers in workably competitive markets.

However, we should caveat this observation in relation to markets where customer inertia is unusually high. Even in workably competitive energy markets, some level of customer inertia remains. And so if regulated price caps were set at an extremely high level and became 'an artificial focal point' amongst rival energy retailers for their default tariff offers (i.e. as distinct from discounted market contract offers), inert consumers on default tariffs would pay more for their energy services than they should. This would represent a legitimate concern of policymakers. But once a truly excessive price has been ruled out (as being most unlikely in practice), the question remains as to whether default tariffs and customer inertia is best dealt with by regulating a price down further and running the risk of price suppression, or whether some other policy initiative might be used to deal with such market imperfections.

In deregulated markets such as New Zealand, when the government became concerned with the high price of default tariffs offered by incumbent retailers, they simply initiated a 'customer switching campaign'. Customer switching rates subsequently jumped from $14 \%$ to $22 \%$ in the space of 12-18 months (VasaETT, 2012). When default tariffs or the price-to-beat increases, it 
typically stokes a competitive market that might otherwise be bordering on inactive, and so any economic rents should gradually be competed away via deeper rival discounting. The critical issue here is the presence of a workably competitive market - if the market is not workably competitive, then by definition the exercise of market power remains possible and price regulation can be justified. But conversely, in workably competitive markets, to the extent that customer inertia might appear to represent a residual market imperfection, it is best dealt with through switching campaigns rather than providing a basis for some form of market-distorting regulatory regime.

For reasons which are not obvious to the authors, despite having among the world's most successful competitive energy pools, regulated retail price caps remain a policy constraint in three of the NEM's four primary regions. Of itself, this represents an oddity and one of the enduring mysteries of Australia's otherwise highly successful market economy. We should acknowledge that while an elaborate set of market institutions have been established to facilitate efficient production and trade, electricity is still considered an essential service by consumers. Yet to be clear, the Victorian region of the NEM has deregulated prices very successfully, so regulation of prices on the grounds of electricity being an essential service makes little sense given the Victorian experience. Electricity is no more essential than housing, food, or health services none of which are regulated. Nonetheless, when governments do regulate the price of a product or service, the political economy becomes particularly complex to navigate in a rising cost environment, as Section 6 later reveals. In the case of electricity, and in extreme cases where price caps are suppressed below fair value in response, a potential chain reaction of events may follow, which we have illustrated in Figure 4. Starting at the top, one such possibility arising from price suppression is over-consumption and if sustained, a requirement for make-up funding through government balance sheets. Next, if tariffs are set sub-optimally, retail competition and product innovation will typically begin to evaporate and investment in new plant can be expected to stall. Ultimately, power system financial flows must be corrected to cost-reflectivity, because the alternate source of power system funding (i.e. government balance sheets and the taxation system) causes distributive inefficiencies. The rate-of-change price shock that follows is likely to be met by a media storm. These issues are considered in the following sections.

Figure 4: $\quad$ Electricity price-suppression domino effect

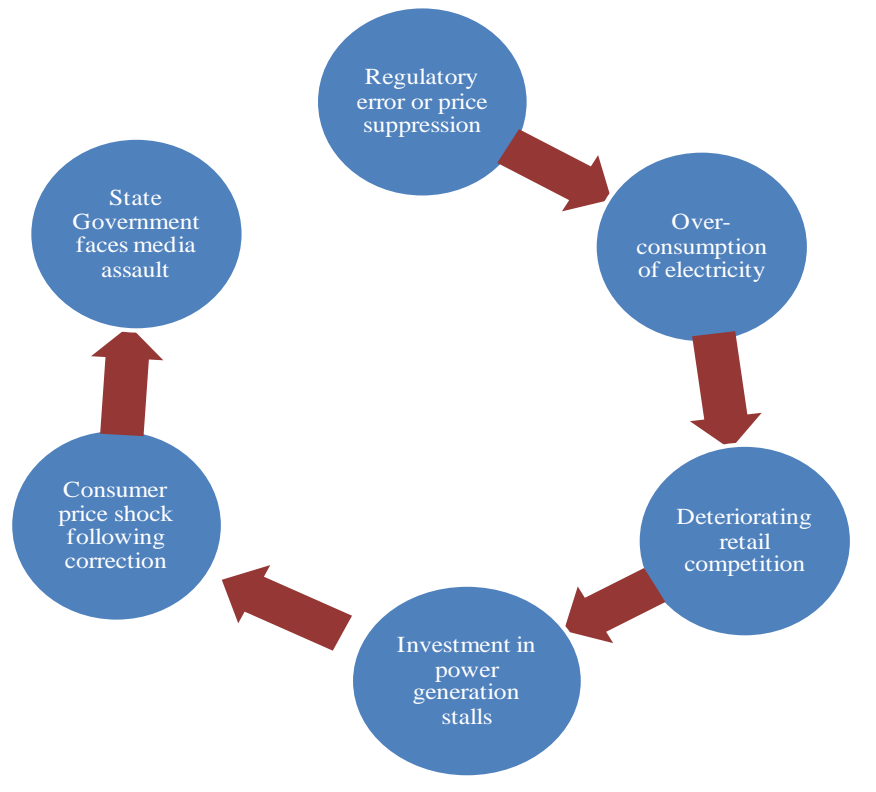




\section{Price suppression: lessons from history}

To begin with, we briefly examine two important case studies. The Californian episode is well known and documented, however it is helpful to draw out some of the key consequences for the purposes of our analysis. We then turn to the case study of Western Australia, which demonstrated a more elongated systemic collapse.

\subsection{The Californian Energy Crisis}

The collision of deregulated wholesale energy markets with regulated retail market tariffs is generally best illustrated by reference to the Californian meltdown of 2000-01. This case study is important because of the sheer magnitude of the collapse. In March 1998, the 45,000MW Californian system introduced full retail contestability following two years of structural reform. As part of the changes, the regulated price-to-beat was frozen at June 1996 levels for four years, and residential and small business customers received a 10 percent reduction on their electricity bills. Regulatory authorities assumed, with considerable justification, that wholesale prices would fall and initially they did (Joskow, 2001).

But by the summer of 2000, the market experienced a substantial increase in the wholesale cost of electricity. Reiss and White (2008) noted that retail prices in 2000 were stable at US\$110/MWh but rose sharply to US\$230/MWh at the start of the physical crisis period. Following the predictable 'bill shock' experienced by customers, there was loud negative public reaction which led the Californian State Government to cap prices (Joskow, 2001). Reiss and White (2008) noted that the artificial price cap was set at about US\$135/MWh.

The existence of retail price caps prevented the two large investor owned utilities, Southern California Edison and Pacific Gas \& Electric from passing-on the high wholesale electricity costs to consumers. Joskow (2001) and Bushnell (2004) noted that both utilities were technically insolvent by early-January 2001. In just six months, a relatively successful electricity reform had collapsed and with it, two of the largest Investor Owned Utilities in the US.

The start of the economic phase of the Californian crisis can be pinpointed to mid-2000 with the rise in wholesale prices and the capping of retail tariffs, while the start of the physical phase occurred towards the end of January 2001. A generally accepted principle in economic theory is that an under-priced commodity will be over-consumed. In Reiss and White (2008), their analysis took the weather-adjusted electricity consumption and billing data for 70,000 households in the San Diego area over a 5-year period spanning either side of the crisis. Prior to the crisis, the 70,000 households consumed an average of $6.1 \mathrm{MWh}$ per annum with electricity tariffs averaging around US\$110/MWh. During the crisis, with electricity tariffs more than doubling from US\$110 to US\$230/MWh, a genuine price-shock event was revealed because customers received their bills with a 3-month lag (and without warning). Between the summer months of June and September of 2000, average household consumption declined by $13 \%$. However, when the Californian State Government artificially suppressed tariffs to $\$ 135 / \mathrm{MWh}$, electricity demand rebounded by $8 \%$.

With the insolvency of the two utilities, independent generators refused to produce power and shutdowns increased from an historical average of $2,500 \mathrm{MW}$ to about $10,000 \mathrm{MW}$. Consequently, the State of California was forced to become the central buyer of electricity and in early 2001 purchased US $\$ 8$ billion in forward contracts to stabilize the grid. ${ }^{14}$

\subsection{The case of Western Australia}

The State Government of Western Australia recently overruled the independent economic regulator's recommended energy tariff increase of $30.2 \%$, opting instead for a $10 \%$ increase due to 'cost of living' pressures. This follows a tortuous history of tariff decisions in Western Australia - in particular, electricity tariffs were frozen for 11 years from 1997/98 largely as a 
result of government policy, which Simshauser, Molyneux and Shepherd (2010) noted translated into a real price reduction of about $30 \%$. Like California, wholesale electricity prices were expected to decline and for the majority of the 11-year freeze, they did. But as Simshauser and Wild (2009) observed, gas prices jumped rapidly from $\$ 3 / \mathrm{GJ}$ to $\$ 8 / \mathrm{GJ}$ due to supply constraints and rising demand from seaborne LNG exports, in the event linking the price of domestic gas to export oil prices for the first time.

With half of Western Australia's power produced by gas-fired generators, a \$5/GJ gas cost increase translates to a roughly $\$ 40 / \mathrm{MWh}$ rise in the running costs of plant, on a base cost of about \$45/MWh. Network investments were, in similar fashion to eastern Australia, running well above trend thereby compounding sharp cost increases. Throughout the three-year period to 2009, rather than keep pace with rapidly rising gas and network costs, residential tariffs were frozen by policy. As a result, in February 2009 the West Australian Office of Energy recommended power prices rise by $116 \%$ over the ensuing 3 year period (a decision which was subsequently rejected). With tariffs set below cost, as was the case in California, one of the State Owned Utilities (Verve Energy) was technically insolvent by early-2008 and was ultimately propped-up by the State. ${ }^{15}$ By mid-2010, the West Australian Energy Minister drew the obvious conclusion:

As a responsible Government, on behalf of the taxpayers of WA, we cannot continue to subsidize Verve's losses... we were left with the reality that a subsidy of almost $\$ 1.5$ billion would be required over three years to keep Verve Energy viable... [Raising electricity prices, thereby] improving the financial position of the corporation [will] ultimately reduce the subsidy paid to cover the difference between the cost reflective price of electricity and the price paid by consumers - taxpayer funds that could be used on other priority areas such as schools, hospitals and roads. ${ }^{16}$

\section{Price suppression, switching velocity and investment rates}

Australia now has the benefit of more than 10 years of competitive energy market data, and so it is useful to examine the NEM's first multi-period episode of over-regulation, which occurred in New South Wales from 2004-2006. Following the introduction of full retail contestability in 2002 , the regulated price cap was regulated below cost in a three-year determination spanning 2004-2006. This is not a contentious observation. Indeed, the New South Wales regulator noted of its own determination that its tariffs were the lowest in Australia and that "there is a need for regulated tariffs to increase" however the determination was designed to "protect small retail customers from significant price shocks" (IPART, 2004, p.1). The Australian Energy Regulator also noted that 'the NEM has had instances where prices were held below cost, such as NSW' (AER, 2009, p.207). This three year period produced two identifiable results: (a) customer switching rates that were clearly at odds with the balance of Australia's NEM, and (b) a merchant investment blackout. On switching rates, Table 1 provides the relevant data. 
Table 1: Annual residential customer switching rates by state 2004-2012

\begin{tabular}{|c|c|c|c|c|c|}
\hline Switch rate (Annual) & NSW & VIC & SA & QLD* & NEM \\
\hline June 2004 & $5 \%$ & $12 \%$ & $11 \%$ & $\mathrm{n} / \mathrm{a}$ & $9 \%$ \\
\hline June 2005 & $6 \%$ & $20 \%$ & $17 \%$ & $\mathrm{n} / \mathrm{a}$ & $13 \%$ \\
\hline June 2006 & $9 \%$ & $21 \%$ & $19 \%$ & $\mathrm{n} / \mathrm{a}$ & $15 \%$ \\
\hline June 2007 & $12 \%$ & $26 \%$ & $11 \%$ & $\mathrm{n} / \mathrm{a}$ & $17 \%$ \\
\hline June 2008 & $10 \%$ & $23 \%$ & $17 \%$ & $16 \%$ & $16 \%$ \\
\hline June 2009 & $11 \%$ & $26 \%$ & $15 \%$ & $17 \%$ & $17 \%$ \\
\hline June 2010 & $13 \%$ & $27 \%$ & $14 \%$ & $18 \%$ & $19 \%$ \\
\hline June 2011 & $14 \%$ & $27 \%$ & $18 \%$ & $25 \%$ & $20 \%$ \\
\hline June 2012 & $17 \%$ & $26 \%$ & $22 \%$ & $21 \%$ & $21 \%$ \\
\hline Total Customers & $3.1 \mathrm{~m}$ & $2.3 \mathrm{~m}$ & $0.7 \mathrm{~m}$ & $1.3 \mathrm{~m}^{*}$ & $7.9 \mathrm{~m}$ \\
\hline Active Retailers & 11 & 14 & 10 & 12 & 21 \\
\hline Total Switching^^ & $50 \%$ & $70 \%$ & $77 \%$ & $66 \%$ & $62 \%$ \\
\hline
\end{tabular}

New South Wales is the largest region of the NEM with 3.1 million customers, and so in theory might be expected to attract the most competitive activity. But note in Table 1 the very low levels of customer switching during the period 2004-2006. Most interesting is the market recovery time - switching rates in New South Wales are only now achieving levels roughly consistent with the balance of the NEM. This delayed recovery time may reflect damage to industry confidence arising from regulation in the first instance.

The other important market result from New South Wales during this period was the absence of investment in merchant power plant. As Simshauser (2012) explains, wholesale market conditions in New South Wales from 2004-2006 were virtually ideal for investment because (a) a looming deficit in supply had been flagged by the Independent Market Operator, (b) the forward curve for electricity contracts was in contango and elevated by comparison to the two neighboring NEM regions of Queensland (to the north) and Victoria (to the south), and (c) spot prices in New South Wales averaged $\$ 42 / \mathrm{MWh}$, while prices in Queensland and Victoria were less than \$35/MWh. ${ }^{17}$ Yet despite these wholesale market conditions, esaa (2010) data reveals that of the $1800 \mathrm{MW}$ of new entrant plant built on Australia's east coast, not a single MW was commissioned in New South Wales between 2004-2007. The entire 1800MW of new plant, representing an investment of just over $\$ 2$ billion, was essentially diverted to the interconnected Queensland and Victorian regions as Table 2 notes.

Table 2: Investment in Merchant Generating Plant from 2004-2010

\begin{tabular}{ccccc}
\hline Region & \multicolumn{2}{c}{$2004-07$} & \multicolumn{2}{c}{$2008-10$} \\
\hline NSW & - & $0 \%$ & $1742 \mathrm{MW}$ & $79 \%$ \\
Vic/Qld & $1814 \mathrm{MW}$ & $100 \%$ & $450 \mathrm{MW}$ & $21 \%$ \\
\hline Total & $1814 \mathrm{MW}$ & $100 \%$ & $2192 \mathrm{MW}$ & $100 \%$ \\
\hline \multicolumn{4}{c}{ Source: data from esaa (2010). }
\end{tabular}

At first glance, these investment results seem counterintuitive. After all, wholesale market conditions during 2004-06 in New South Wales were more favourable - it was only retail market conditions that were distorted by way of price cap regulation. But as Finon (2008) and Simshauser (2010) observed, and as Nelson and Simshauser (2012) demonstrate, merchant power projects relying on 2-3 year hedge contracts for entry became completely "un-bankable" from the mid-2000s. The 'merchant model' is essentially broken. The critical precondition for plant entry in energy-only markets is the presence of a Power Purchase Agreement (PPA), written by an investment-grade credit-rated entity as Simshauser (2010) explains in some detail. And so if 
retail tariff caps are artificially suppressed through price regulation, PPAs will by definition become uneconomic instruments. The issue here is simple - if PPAs are uneconomic for integrated (investment grade credit-rated) retailers to write, none will be written, and so investment cannot be facilitated. Instead, in this instance, PPAs remained economic in neighboring regions where retail prices were not suppressed and so this is where investment flows were directed. In the event, the higher loading of inter-regional transmission lines ensured security of supply was met in New South Wales. One might be tempted to argue that 'the market worked'. But this misses the point - any pragmatic analysis would conclude the market worked more by luck than management.

Perhaps predictably, when the regulated price cap was revised upwards in New South Wales from 2007 onwards using a framework that was compatible with the competitive market environment, investment in NSW surged, and accounted for $79 \%$ of all fixed plant additions on the east coast from 2008-2010 as Table 2 notes. In all, the New South Wales regulatory episode of 2004-2006 and the subsequent correction to tariffs provides policymakers with important observations on the link between retail market conditions, and the flow of investment into the industry's supply side in energy-only markets.

The most recent regulatory episode in Queensland in 2012 appears to display the hallmarks of a once intensely competitive market slowing to, at best, stall speed. Of course, at the time of writing it is too early to make a definitive assessment of the impact arising from the regulators' 2012 decision. However, market data available at the time of drafting seem to indicate that (a) the velocity of absolute customer switching has fallen by $20 \%$ year-on-year, (b) rival retailer marketing efforts have contracted significantly, with field-staff reducing by $56 \%$ year-on-year, and (c) tariff discounts have diminished by an average of 3-5 percentage points, with at least two competitors seemingly retreating from the market altogether.

Figure 5 provides a time-series of customer switching in Queensland using aggregated monthly data from June 2008 to August 2012. But rather than measure switching rates as an overall percentage of the market (i.e. the typical "annualized switching rate"), we present the year-onyear change in the absolute number of customers who have switched over the preceding 12 month period, at monthly resolution. So for example, for the 12 months ending August 2012, a total of 260,059 households had switched retailer, whereas for the 12 months ending August 2011, a total of 326,072 customers had switched. As such, the annual velocity of customer switching in September 2009 had fallen by $20.2 \%$, year-on-year. 
Figure 5: Annual velocity of customer switching (absolute year-on-year change)

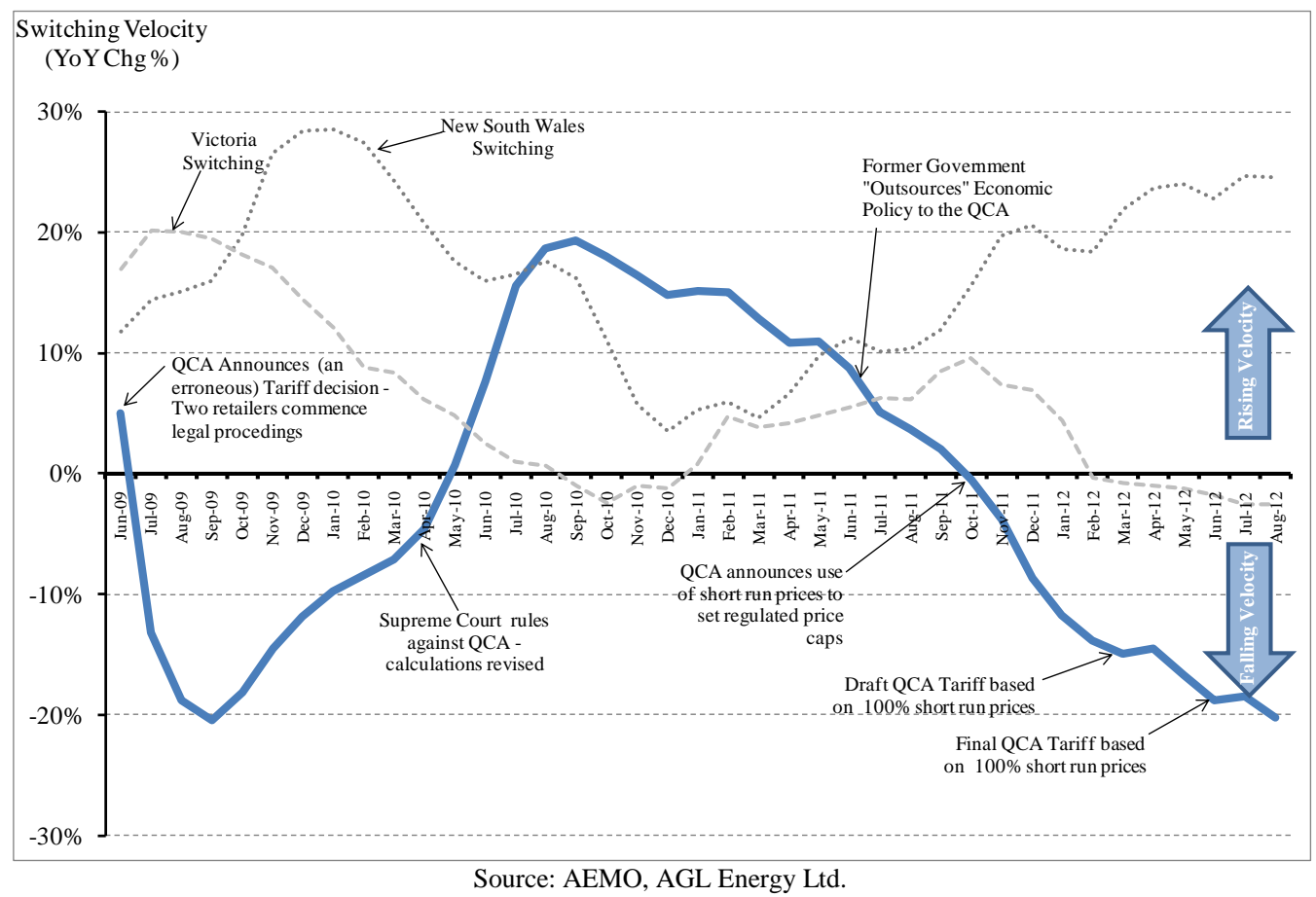

In Figure 5, the solid line illustrates the annual change in customer switching velocity in Queensland. For comparative purposes, Victoria and New South Wales have also been included. Note that when results are non-negative, market activity is intensifying and conversely, when the time-series falls below the origin, market activity is contracting. To be clear, customer switching will inevitably cycle above and below a zero result. Victoria, the world's most competitive retail energy market, confirms such results. But sharply negative results are a signal that competitive intensity is demonstrably contracting.

Note that there are two notable 'troughs' in Figure 5 relating to Queensland. The first occurred immediately after an 'erroneous' regulatory decision in June 2009. We have opted to largely over-look this episode in our analysis because while switching rates plunged, they recovered almost as quickly (i.e. by the third quarter of the same financial year) when a Supreme Court challenge ruled against the regulator and the decision was 'corrected'. The second trough coincides with the 2012 regulatory episode, in which the Government outsourced the economic policy (i.e. triggering an initial crisis of confidence), which was intensified by the regulator's announcement to a regulatory framework excluding long run costs, and crystallized in their draft and final regulatory decisions whereby the wholesale energy cost allowance was set below long run costs.

How retailers respond to a positive or negative regulatory event is primarily through marketing resources deployed - increasing or winding back activity, and increasing or reducing the level of product discounts on offer. This is illustrated in Figure 6. The bars in Figure 6 measure the number of field resources (otherwise known as door-knockers) on a monthly basis from June 2009 through to August 2012. Once again two troughs can be seen - the first coinciding with the erroneous determination in mid-2009. Notice also the run-up in field staff once the Supreme Court ruled against the regulator. There is a considerable burst in activity from Jul-Dec 2010. While not evident from data contained in Figures 5 and 6, a sharp run-up in marketing activity occurred in South Australia from January 2011, and this presumably led to redeployment of limited (marketing budget) resources to that state, hence the apparent reduction in Queensland. From Jan-Sep 2011, field resources remained largely constant but once it became clear that the State Government was not going to set the regulatory framework, a contraction in field resources 
began. In late-2011, the Queensland regulator announced that its preferred method for determining tariff caps would be to use only short run spot and contract prices. The draft regulatory decision in March 2012 and the final in June 2012 confirmed this approach and both field resources and switching velocity continued to plunge at the time of writing.

Figure 6: $\quad$ Retailer field marketing activity vs. customer switching velocity

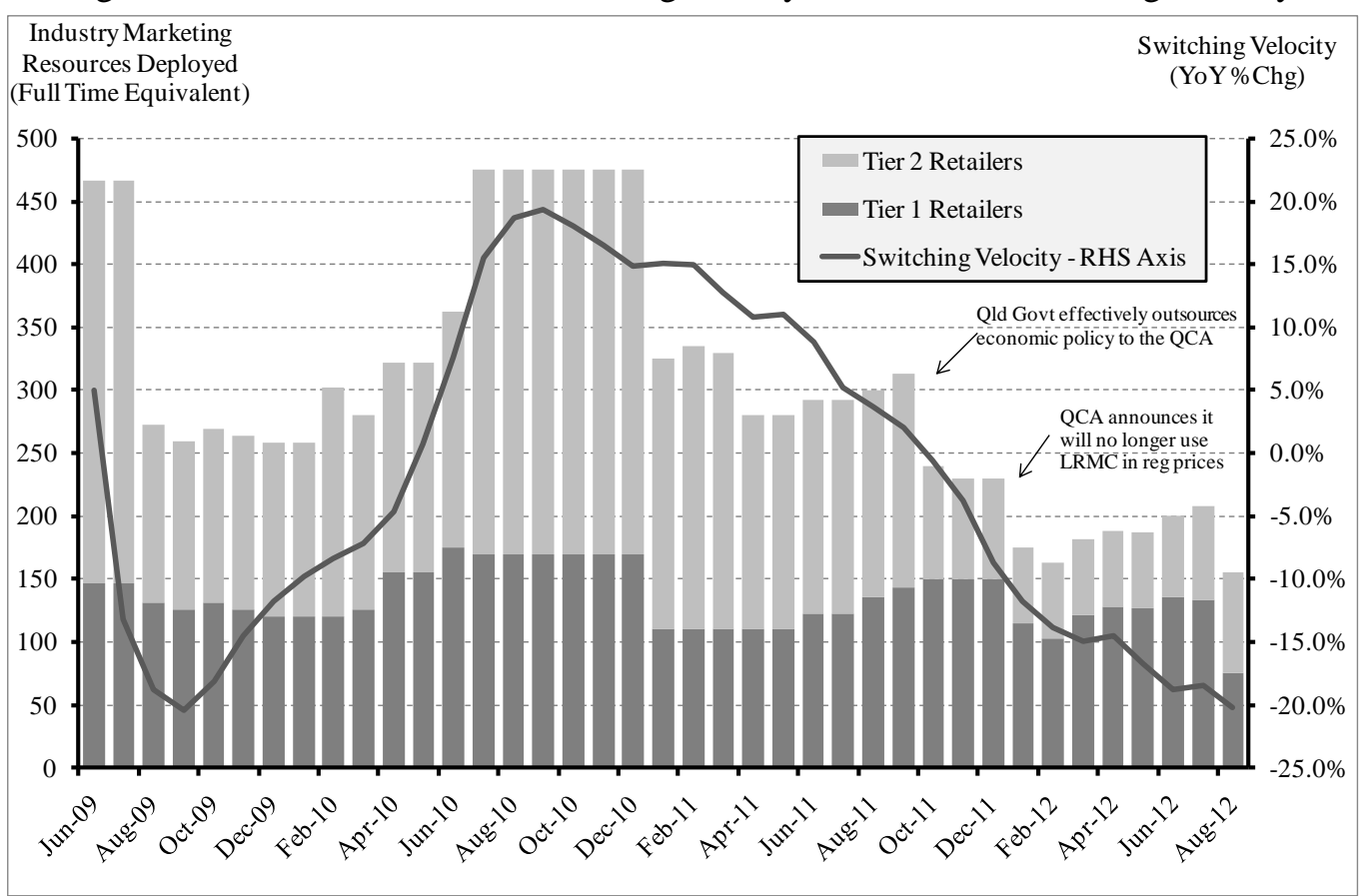

Source: AGL Energy Ltd.

\section{The tyranny of regulated price announcements for Governments}

Where retail tariffs are regulated, presiding Governments will at times face an unusually hostile reception from the media as a price determination is being announced. This has been prominent in Australia over the past few years as part of a broader 'cost of living' thematic in the media, and accordingly, we investigated the incidence and intensity of press reactions to governmentannounced electricity tariff increases.

By way of brief background, the so-called 'cost of living' is currently dominating the furious 24hour media cycle, and along with housing-related mortgage costs, electricity prices appear to have found a special place with Australian journalists as Figure 7 later reveals. This is not entirely surprising given that over the last three September quarters ${ }^{18,19}$, electricity price rises have been a prominent variable in Australia's Consumer Price Index. Yet surprisingly, as a percentage of average Australian household expenditure, for the past 20 years energy costs have remained constant at just $2.6 \%$, far exceeded by housing (18\%), food (15\%), health $(5.3 \%)$ and even alcohol and tobacco $(3.6 \%) .{ }^{20}$ The prominence of electricity tariff increases in the media therefore relates to the 'rate of change' - not absolute expenditure on energy.

Our potential chain-reaction of events outlined in Figure 4 culminates in adverse media for the presiding government (and industry) because when an over-regulated tariff is eventually restored to long run efficient levels, it typically occurs quickly, and can result in 'bill shock'. But in addition to the 'rate of change' issue, for reasons which become clearer later in this section, the reality is that electricity consumers (i.e. voters) react badly to price increases announced by governments. This is a particularly vexed issue. 
We conducted an analysis of media commentary on retail electricity prices from 2007-2011 with the results displayed in Figure 7. 'Media events' refer to any reference to the term electricity price (which we have, quite reasonably, assumed in all cases to be a bad news story), and has been drawn from a comprehensive analysis of newspapers, radio and television across the four largest NEM regions. We first undertook this analysis in July 2011, and extended the analysis to capture a further 12 months of data in July 2012. In our analysis below, note that we isolate our 2011 result (Figure 7) from our 2012 result (Figure 8) quite deliberately. The reason for doing so is that a carbon tax policy was formed and implemented by the federal government immediately after our 2011 result. Therefore, by keeping the two analyses separate, we are able to identify, at least partially, the media effects arising from the announcement and implementation of the NEMwide carbon tax.

To begin with, Figure 7 illustrates the 'media events' from 2007 to 2011, with the 2011 result being 'annualised' because only 6 months of data was available at the time the analysis was undertaken. Recall from Figure 1 that prices began to rise sharply from about 2008, involving a pronounced 'rate-of-change'. Consequently, one would expect to see material increases in media events in all regions from 2008 onwards. Yet in the two regions that had been fully privatized, Victoria and South Australia, media attention was lowest. In Victoria, retail prices were deregulated in 2008, and so there is no government announcement of price rises and interestingly, media events reduced. In South Australia, an independent regulator announces the tariff increase but for the most part, their rises were comparatively stable given the extensive use of long run marginal cost-reflective tariff caps.

In contrast, the two states in which non-trivial components of the electricity supply chain remain in public ownership, where the rate of change was highest, and importantly, where the price regulation process remains intensive - experienced the greatest increases in media, up $670 \%$ in New South Wales and 620\% in Queensland from a 2007 base year. We noted earlier that New South Wales had over-regulated prices from 2004-2006 and so the rate-of-change issue was most pronounced in New South Wales, as was media attention.

Figure 7: $\quad$ Analysis of electricity price 'media events' in the NEM as at July 2011

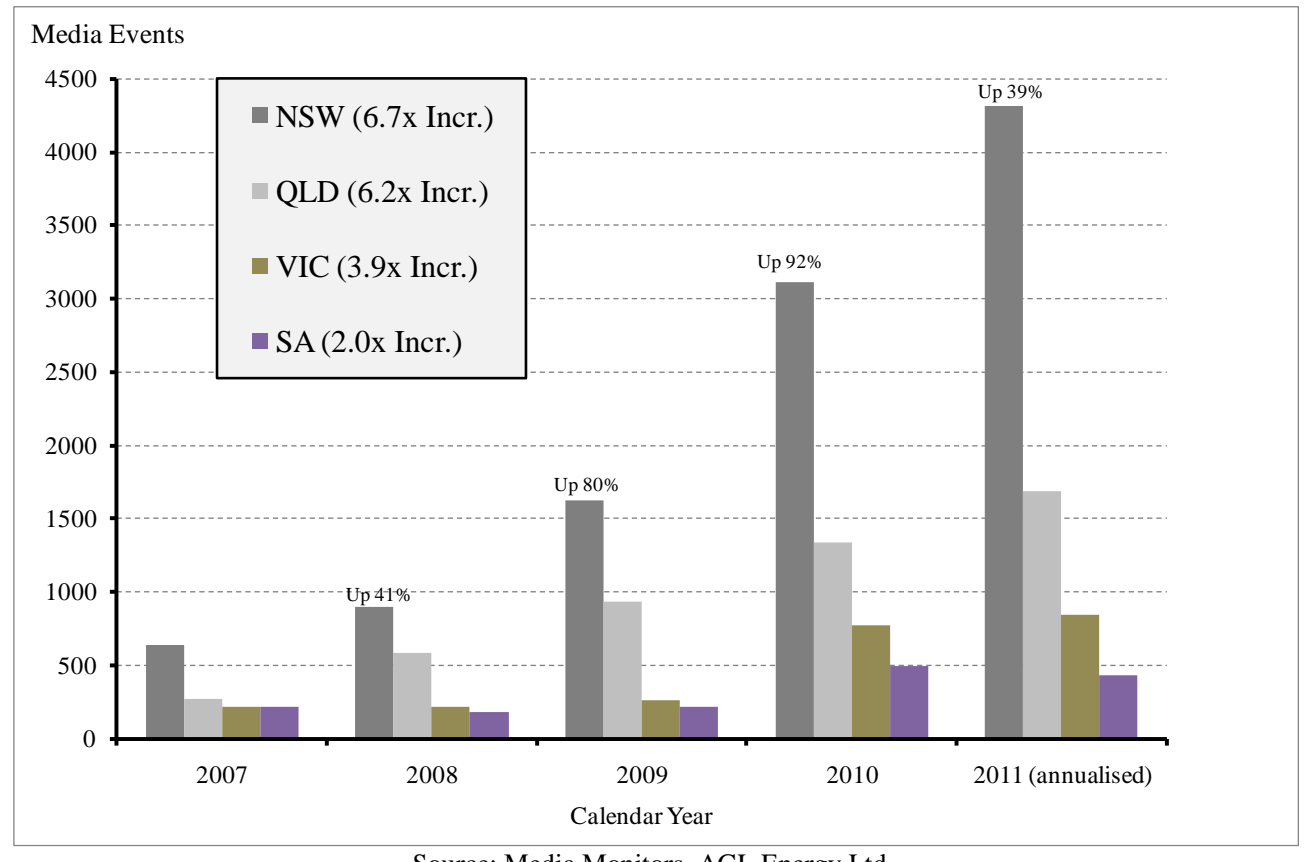

Source: Media Monitors, AGL Energy Ltd. 
Despite the fact that independent authorities in Queensland and New South Wales have regulatory oversight and decision making powers over determining the retail price-to-beat, state governments are invariably (and perhaps unfairly) implicated. The editors of The Courier Mail, Queensland's principle newspaper, drew the obvious conclusion following the predictable annual assault on the state government by their own journalists:

The State Government should accept the inevitable and fully deregulate the state's retail electricity markets. Not only would this provide consumers with a greater choice of retailers and more competition - the whole point of deregulation - but it would also free the Government from the regular public beating it receives at this time each year when the Queensland Competition Authority announces the electricity price increase for the next 12 months... Every step of the way the state energy minister of the moment has found themselves in the uncomfortable position of having to express public regret at the increases and trying to sound as if the Government can do something about them, while knowing full well that in reality it can do little but watch... (Courier Mail Editorial, 5 May 2010).

Applied economic research provides some insight into the incidence of negative media for state governments in relation to retail price regulation in a rising cost environment. Savage and Torgler's (2010) study into perceptions of fairness in allocation systems provides one such example. They considered reactions to an excess demand situation whereby the price of bottled water in a remote location was increased (i.e. doubled) to clear market demand. Two of their scenarios were relevant to our research. In the first, a private vendor chose to double the price of bottled water and in the second, a government authority was responsible for doing so in order to clear demand. Roughly 100 survey respondents were asked whether they thought the marketclearing price was 'fair'. The results of their analysis have been reproduced in Table 3:

Table 3: Fairness of pricing decisions - private sector vs. Government

\begin{tabular}{|l|c|c|}
\hline & $\begin{array}{c}\text { Price Increase by } \\
\text { Private Sector }\end{array}$ & $\begin{array}{c}\text { Price Increase } \\
\text { by Government }\end{array}$ \\
\hline Unfair & $19.4 \%$ & $46.2 \%$ \\
\hline Acceptable & $53.8 \%$ & $40.9 \%$ \\
\hline Fair & $26.9 \%$ & $12.9 \%$ \\
\hline & & $\begin{array}{c}\text { Government vs. } \\
\text { Private }\end{array}$ \\
\hline Less Acceptable & & $51.6 \%$ \\
\hline Equally Acceptable & & $36.6 \%$ \\
\hline More Acceptable & & $11.8 \%$ \\
\hline
\end{tabular}

Source: Savage and Torgler (2010)

Note that when the private sector raised the price for this essential commodity (i.e. bottled water in a remote location) more than $80 \%$ found this to be either acceptable $(53.8 \%)$ or fair $(26.9 \%)$. However, when Government was associated with raising the price, $46.2 \%$ of participants found this to be unfair. When asked separately whether they found the notion of the price rise to be more or less acceptable via government involvement, $51.6 \%$ of participants found it 'less acceptable'. In short, the public, it would appear, have a greater tolerance or level of acceptance to rising prices when the organizations announcing the increase have a profit motive. While the public may not like the price increase, they can at least understand the logic and the motive. However, it appears difficult for much of the voting public to understand why congestion pricing should be applied by a government when they will bear the cost-consequence.

In Figure 8, we illustrate a 2012 update of our media analysis which was conducted 12 months after the initial analysis in July 2011. In Figure 8, note that the 2011 results are no longer 
annualized (as was the case in Figure 7) because actual results were able to be collated. However, the 2012 result is necessarily annualized due to only 6 months of actual results being available at the time of drafting.

In comparing Figure 8 with Figure 7, the stand-out feature of the updated data is the rise in 2012 media events in all regions, including Victoria and South Australia. Why was this? The additional data presented in Figure 8 (by comparison to Figure 7) incorporates the period when the federal government announced and implemented a carbon tax. This federal government announcement of electricity price increases applied to all regions, including Victoria and South Australia.

Figure 8: $\quad$ Analysis of electricity price 'media events' in the NEM as at July 2012

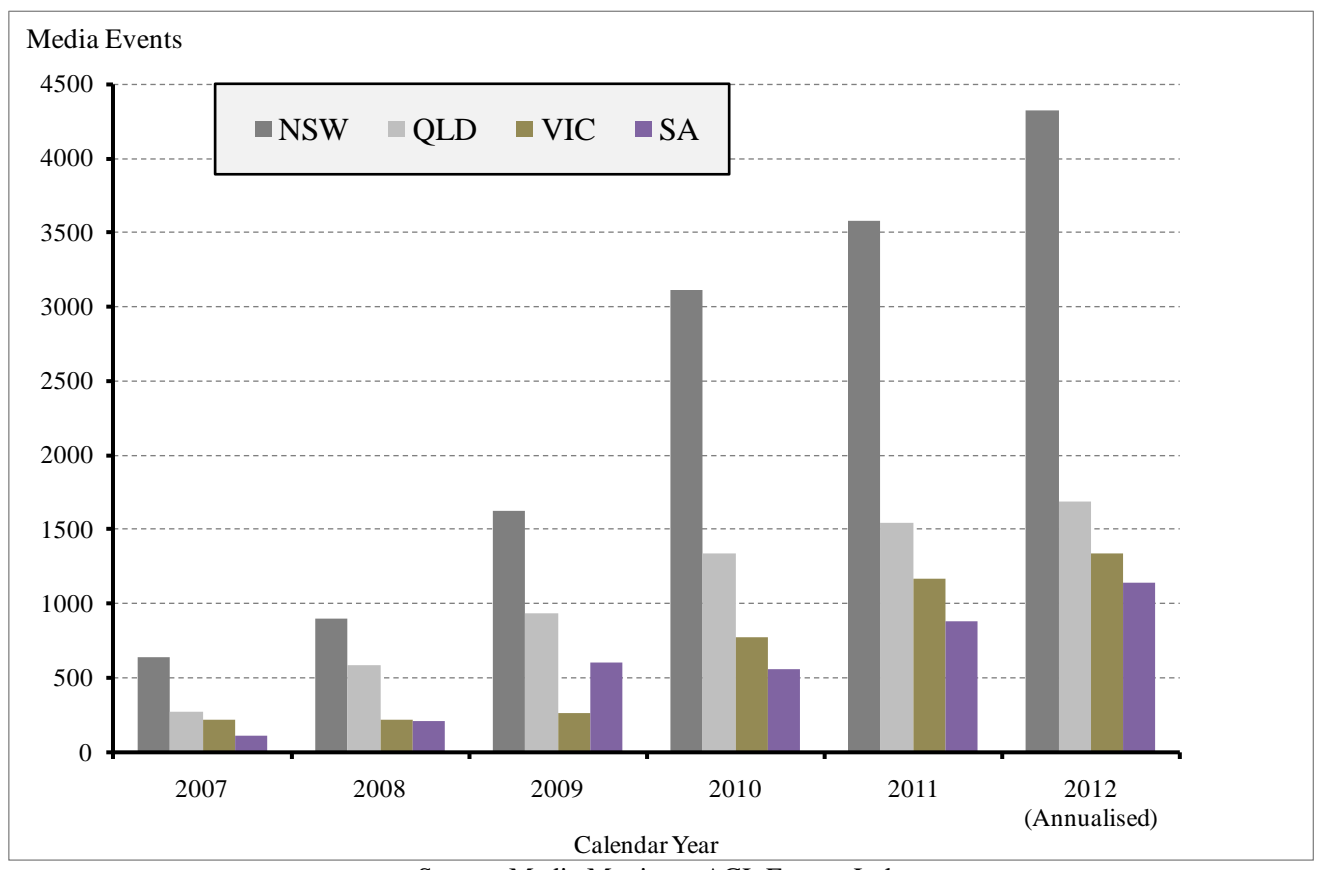

Source: Media Monitors, AGL Energy Ltd.

\section{Concluding remarks}

The purpose of this article was to outline a potential chain reaction of events that might be expected to arise under conditions of regulatory-induced electricity price suppression in workably competitive energy markets. We reviewed the special case of California where power prices were suppressed, which resulted in energy demand experiencing a rebound of $8 \%$ on the preceding period. We found that pricing shortfalls in power systems ultimately required the use of State Government Balance Sheets to stabilize the system, physically and systemically in California and Western Australia, respectively. Ultimately, if prices are inadequate on a sustained basis, government intervention will be required if the lights are to stay on. Like many things in economics, it's obvious once you think about it.

Our analysis of customer switching under conditions of price suppression in New South Wales from 2004-2006 found that by comparison to the balance of the NEM, the competitive market was paralyzed with switching rates as low as 5\%. The link between, and impact on, the flow of investment into merchant power plants during an episode of regulatory-induced retail price suppression was also examined. We found that during 2004-2007 in New South Wales, despite having favourable wholesale market conditions for investment, new plant was instead developed in the two adjacent regions of Queensland and Victoria. The reason for this was that front-end integrated cost recovery was intractable in New South Wales and thus writing PPAs was a subeconomic activity, and front-end investment yields are important to capital-constrained energy 
utilities as Nelson and Simshauser (2012) explain. We also found that when the regulated price cap was corrected, almost $\$ 2$ billion of investment in fixed plant flowed quite rapidly into New South Wales, accounting for $79 \%$ of all new investment in the subsequent few years. More recent data from Queensland indicates that regulatory-induced price suppression has resulted in a rapidly decelerating switching velocity, driven by a reduction in marketing field resources deployed.

We also noted that household energy costs have remained constant at $2.6 \%$ for the past 20 years. While electricity price increases have been substantial, growth in the average earnings of Australians has also been strong. In simple terms, a $10 \%$ increase in the $\$ 1500$ yearly household electricity bill is readily accommodated by persistent $3.6 \%$ pa increases in the currently $\$ 69,000$ average annual earnings of the Australian workforce. However, the price restoration process in New South Wales from the lows of the 2004-2006 determination involved non-trivial price increases from 2007 and were then compounded by sharply rising network costs, and we believe the electricity price rate of change was primarily responsible for attracting the considerable public outrage and substantial media attention that occurred. Queensland also underwent large increases, albeit off a slightly higher base and slower rate of change. Above all, our analysis of the media treatment of price increases revealed that those regions where Government remains involved in price determinations and retains some ownership of energy assets face an annual assault by the media. Interestingly, in Victoria media coverage of electricity price rises declined after the Government exited the price-setting arena. However, we also found that all regions experienced a step-change in media coverage due to the Federal Government's announcement of a carbon tax.

Given the sheer complexity of competitive electricity pools, for a regulator seeking to fine-tune a perfectly efficient price, the notion of regulatory error and its impacts are far more than a theoretical possibility. We highlighted a potential domino effect which commenced with overconsumption, a reduction in competition, declining investment in generating equipment, culminating in a future price shock and a media assault. Following the likely media assault driven by the rate-of-change in prices required to restore industry systemic stability, the more interesting scenario is what happens next. Given the political economy of electricity prices, it is not hard to envisage our domino effect becoming a particularly vicious cycle capable of completing more than 'one iteration' before finally being short-circuited through policy intervention, or indeed, retraction. To avoid such a mess from occurring at the outset, the public policy objective of electricity price regulation needs to be especially clearly articulated to guide policymaking and implementation. Of course, price regulation serves no economic purpose in a workably competitive market. But if it forms a policy constraint due to the political economy of electricity prices, it should reflect a safety-net price so as to not distort the proper functioning of the market as Simshauser (2012) explains. However, based on the Victorian experience, the path of least resistance seems clear enough. To neutralise the risks associated with our potential domino effect, in workably competitive markets, any state-based regulated pricing controls should be removed and the market liberalized, whilst simultaneously ensuring suitable switching campaign strategies and hardship policies exist.

\section{References}

Bushnell, J. (2004), “California’s electricity crisis: a market apart?”, Energy Policy, 32(9): 1045-1052.

Bushnell, J. (2005), "Electricity Resource Adequacy: matching policies and goals", The Electricity Journal, 18(8): 11-21.

esaa: Energy Supply Association of Australia, (2010), Electricity Gas Australia, esaa publication, Melbourne.

Felder, F. (2010), "The practical equity implications of advanced metering infrastructure", The Electricity Journal, 23(6): 56-64. 
Finon, D. (2008), "Investment risk allocation in decentralised markets: the need of long-term contracts and vertical integration”, OPEC Energy Review, 32(2): 150-183.

IEA: International Energy Agency, (2005), "Energy Policies of IEA Countries - Australia 2005 Review", IEA Publication, Paris. Available at http://www.iea.org/textbase/nppdf/free/2005/australia2005.pdf

IPART, 2004, “NSW Electricity Regulated Tariffs 2004/05 to 2006/07: Final Report and Determination”, IPART Publication, Sydney. Available at http://www.ipart.nsw.gov.au

IPART, 2011, “Changes in regulated electricity retail prices from 1 July 2011”, IPART Publication, Final Report June 2011, Sydney. Available at http://www.ipart.nsw.gov.au

Joskow, P. (2001), “California’s electricity crisis”, Oxford Review of Economic Policy, 17(3): 365-389.

Joskow, P. (2006), "Competitive electricity markets and investment in new generating capacity", Center for Energy and Environmental Policy Research Working Paper 06-009. Available at http://econpapers.repec.org/paper/meewpaper/0609.htm

NCC: National Competition Council, (2003), “2003 NCP assessment”, National Competition Council Publication, Melbourne. Available at http://ncp.ncc.gov.au/docs/2003\%20assessment.pdf

Nelson, J. and Simshauser, P. (2012), "Is the merchant power producer a broken model?", AGL Applied Economic and Policy Research Working Paper No. 32, Brisbane. Available at www.aglblog.com.au

Parer, W. (2002), "Towards a truly national and efficient energy market”, Council of Australian Governments Energy Market Review, Commonwealth of Australia, Canberra. Available at http://www.ret.gov.au/Documents/mce/_documents/FinalReport20December200220050602124631.pdf

QCA: Queensland Competition Authority. 2012, "Regulated Retail Electricity Prices 2012-13", Final Determination, May 2012, Brisbane. Available at www.qca.org.au

Reiss, P. and White M. (2008), "What changes energy consumption? Prices and public pressure", RAND Journal of Economics, 39(3):636-663.

Savage, D. and Torgler, B. (2010), "Perceptions of fairness and allocation systems", Economics Analysis and Policy, 40(2): 229-248.

Simshauser, P. (2010), "Vertical integration, credit ratings and retail price settings in energy only markets: navigating the Resource Adequacy problem”, Energy Policy, 38(11): 7427-7441.

Simshauser, P. (2012), "When does retail electricity price regulation become distortionary?", AGL Applied Economic and Policy Research Working Paper No. 33, Brisbane. Available at www.aglblog.com.au

Simshauser, P. and Catt, A. (2012), "Dividend policy, energy utilities and the investment megacycle", The Electricity Journal, 25(4): 63-87.

Simshauser, P., Molyneux, E. and Shepherd, M. (2010), "The entry cost shock and the re-rating of power prices in NSW, Australia”, Australian Economic Review, 43(2): 114-135.

Simshauser, P., Nelson, T. and Doan, T. (2011), “The Boomerang Paradox, Part I: how a nation's wealth is creating fuel poverty", The Electricity Journal, 24(1):72-91.

Simshauser, P. and Wild, P. (2009), "The Western Australian power dilemma”, Australian Economic Papers, 48(4): 342-369.

SSC: Smart State Council, (2010), An EnergySmart Plan: positioning Queensland for a diversified energy future 2010-2050, Queensland Government Publication, Brisbane. 
VaasaETT (2012), "World energy retail market rankings", VaasaETT publication, available at www.vaasaett.com.

Yarrow, G. 2008, "Report on the Impact of Maintaining Price Regulation”, Regulatory Policy Institute, Oxford, United Kingdom.

${ }^{1}$ Paul Simshauser is the Chief Economist \& Group Head of Corporate Affairs at AGL. He is also Professor of Economics at Griffith University's Business School. Dr Kay Laochumnanvanit is Customer Insights Manager at National Australia Bank. Any errors or omissions remain the responsibility of the authors.

${ }^{2}$ The privatised Victorian distribution network businesses have also delivered substantial performance efficiency benefits.

${ }^{3}$ There are also considerable reforms required with respect to the monopoly network businesses, including a review of reliability standards and ownership structures in Queensland and New South Wales.

${ }^{4}$ NSW new entrant electricity retailer 'EnergyOne' collapsed during 2007 and Jackgreen also collapsed, in 2009.

${ }_{6}^{5}$ For details, see QCA (2012).

${ }^{6}$ Price regulation for monopoly industries invariably involves setting prices at industry long run marginal cost or some representation of an efficient average unit cost.

${ }^{7}$ To be clear, a non-negative retail margin exists, albeit at greatly diminished levels given negative wholesale margins. The regulator allowed a $5.4 \%$ retail margin and an additional 5\% 'headroom' in the price cap.

${ }^{8}$ Following the QCA (2012) decision, an inquiry followed in South Australia (ESCOSA, 2012) and the New South Wales regulator

also announced their preference for using short term contract prices to set tariff caps (see IPART, 2011).

${ }^{9}$ See for example Moore, B. and Ryall, S. (2012), "Regulatory risk not priced", CLSA Asia Pacific Markets, Sydney.

${ }^{10}$ See in particular Simshauser, Nelson and Doan (2011) and especially Figure 8 at page 86 for an analysis of network capital expenditures between 2000 and 2015 .

${ }^{11}$ Peak demand in the Queensland region of the NEM increased by a surprisingly large 104\% over the 12-year period to FY10, while population growth was only 35\% (Simshauser, Nelson and Doan, 2011).

${ }^{12}$ See SSC (2010).

${ }^{13}$ Simshauser (2012) explains in considerable detail the basis of the policy change by the regulatory authorities.

${ }^{14}$ This occurred via California Legislature passing Assembly Bill 1X, which among other things allowed the State Government to take over the bulk of the purchasing responsibilities from the two 'financially moribund' utilities (Bushnell, 2004).

${ }^{15}$ To put the extent of the subsidy into perspective, aggregate residential load in Western Australia was at that time about 5,875GWh

per annum, while households were charged about $\$ 230 / \mathrm{MWh}$. If we assume the three-year, $\$ 1.5$ billion subsidy is incurred evenly at $\$ 500 \mathrm{~m}$ per annum, then the 909,000 households are being subsidized at the rate of about $\$ 85 / \mathrm{MWh}$ over and above prevailing electricity tariffs. Once again, in Western Australia as with California, consumers inevitably pay via electricity bills or via the taxation system subsidies which as the Energy Minister correctly noted, has subsequent implications for other welfare objective functions such as education, transportation and health, not to mention the acute adverse effects on distributive efficiency since those being subsidised the most would inevitably be high-income households, given the positive correlation between electricity consumption and income (Felder, 2010).

${ }^{16}$ Ministerial Media Statement, Peter Collier, Western Australian Minister for Energy, 21 September 2010. Available at

http://www.mediastatements.wa.gov.au/Pages/Default.aspx?ItemId=134025\&

${ }^{17}$ For further details of the comparative wholesale market conditions, see Simshauser (2012).

${ }^{18}$ Electricity tariff increases are generally implemented at the start of each new financial year, which commences from 1 July.

${ }^{19}$ In Sep-11, electricity prices increased by $7.8 \%$, the Sep- 10 was $6.0 \%$ and Sep- 09 was $11.4 \%$. See www.abs.gov.au

${ }^{20}$ Average household income in Australia is about $\$ 69,000$ pa and is rising at 3.6\% pa, compared to movements in the consumer price index of about 2-3\% pa. Average annual electricity bills of $\$ 1500$ are rising at about $10 \%$ pa. So while energy costs have been rising quickly, annual household income is also rising off a much higher base (albeit at a lower rate) and as a consequence, energy has remained a largely constant component of average household expenditure. 